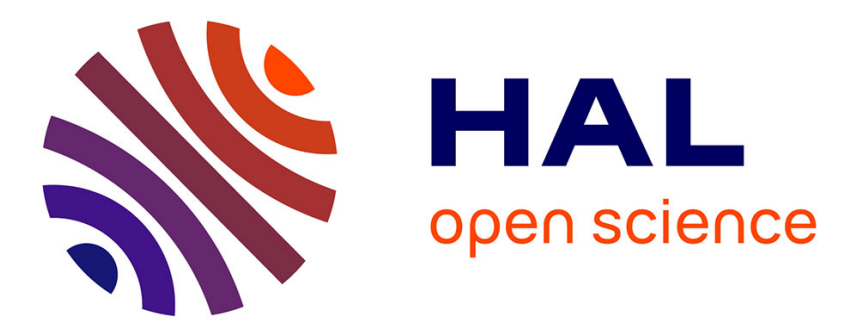

\title{
Potential cobalt limitation of vitamin B12 synthesis in the North Atlantic Ocean
}

\author{
C. Panzeca, A. Beck, Karine Leblanc, G.T. Taylor, D.A. Hutchins, Sergio A. \\ Sanudo-Wilhelmy
}

\section{> To cite this version:}

C. Panzeca, A. Beck, Karine Leblanc, G.T. Taylor, D.A. Hutchins, et al.. Potential cobalt limitation of vitamin B12 synthesis in the North Atlantic Ocean. Global Biogeochemical Cycles, 2008, 22 (GB2029), 7 pp. 10.1029/2007GB003124 . hal-00702673

\section{HAL Id: hal-00702673 https://hal.science/hal-00702673}

Submitted on 22 Nov 2021

HAL is a multi-disciplinary open access archive for the deposit and dissemination of scientific research documents, whether they are published or not. The documents may come from teaching and research institutions in France or abroad, or from public or private research centers.
L'archive ouverte pluridisciplinaire HAL, est destinée au dépôt et à la diffusion de documents scientifiques de niveau recherche, publiés ou non, émanant des établissements d'enseignement et de recherche français ou étrangers, des laboratoires publics ou privés.

$$
\text { Copyright }
$$




\title{
Potential cobalt limitation of vitamin $B_{12}$ synthesis in the North Atlantic Ocean
}

\author{
C. Panzeca, ${ }^{1}$ A. J. Beck, ${ }^{1}$ K. Leblanc, ${ }^{2}$ G. T. Taylor, ${ }^{1}$ D. A. Hutchins, ${ }^{3}$ and \\ S. A. Sañudo-Wilhelmy ${ }^{3}$
}

Received 15 October 2007; revised 11 February 2008; accepted 21 February 2008; published 26 June 2008.

[1] While recent studies have confirmed the ecological importance of vitamin $\mathrm{B}_{12}$, it is unclear whether the production of this vitamin could be limited by dissolved $\mathrm{Co}$, a trace metal required for $\mathrm{B}_{12}$ biosynthesis, but found at only subnanomolar concentrations in the open ocean. Herein, we demonstrate that the spatial distribution of dissolved $\mathrm{B}_{12}$ (range: $0.13-5 \mathrm{pmol} \mathrm{L}^{-1}$ ) in the North Atlantic Ocean follows the abundance of total dissolved Co (range: $15-81 \mathrm{pmol} \mathrm{L}^{-1}$ ). Similar patterns were observed for bacterial productivity (range: $20-103 \mathrm{pmol}^{3} \mathrm{H}$ leucine $\mathrm{L}^{-1} \mathrm{hr}^{-1}$ ) and algal biomass (range: $0.4-$ $3.9 \mu \mathrm{g} \mathrm{L}^{-1}$ ). In contrast, vitamin $\mathrm{B}_{1}$ concentrations (range: $0.7-30 \mathrm{pM}$ ) were decoupled from both $\mathrm{Co}$ and $\mathrm{B}_{12}$ concentrations. Cobalt amendment experiments carried out in low-dissolved Co waters $\left(\sim 20\right.$ pmol L $\left.{ }^{-1}\right)$ enhanced $\mathrm{B}_{12}$ production two-fold over unamended controls. This study provides evidence that $\mathrm{B}_{12}$ synthesis could be limited by the availability of $\mathrm{Co}$ in some regions of the world ocean.

Citation: Panzeca, C., A. J. Beck, K. Leblanc, G. T. Taylor, D. A. Hutchins, and S. A. Sañudo-Wilhelmy (2008), Potential cobalt limitation of vitamin $\mathrm{B}_{12}$ synthesis in the North Atlantic Ocean, Global Biogeochem. Cycles, 22, GB2029, doi:10.1029/2007GB003124.

\section{Introduction}

[2] Vitamin $B_{12}$ availability plays an important role in marine ecosystems as it is required for the synthesis of several vital enzymes, including methylmalonyl-CoA mutase, methionine synthase and type II ribonucleotide reductase [Raux et al., 2000; Martens et al., 2002]. However, actual cellular quotas for vitamin $\mathrm{B}_{12}$ among phytoplankton taxa are largely unknown [Carlucci and Bowes, 1972; Croft et al., 2006; Droop, 2007]. In the few species for which $\mathrm{B}_{12}$ growth kinetics data are available, half-saturation constants, $\mathrm{K}_{\mathrm{s}}$, average $1.4 \mathrm{pmol} \mathrm{L}^{-1}$ ( $\pm 2.6 \mathrm{SD}$ [Droop, 2007]), which is within the range of ambient open ocean concentrations of $0.3-2.4$ pmol L ${ }^{-1}$ [Panzeca, 2007]. This suggests that in some areas of the world's oceans some phytoplankton taxa are exposed to subsaturating vitamin $\mathrm{B}_{12}$ concentrations, essentially living under a vitamin-limiting regime. In fact, recent experimental results from both coastal and open ocean environments clearly demonstrate that ambient levels of dissolved $\mathrm{B}_{12}$ were growth-limiting because phytoplankton abundance was enhanced and community structure was altered by $\mathrm{B}_{12}$ amendments [Sañudo-Wilhelmy et al., 2006;

\footnotetext{
${ }^{1}$ School of Marine and Atmospheric Sciences, Stony Brook University, Stony Brook, New York, USA.

${ }^{2}$ Laboratoire d'Océanographie et de Biogéochimie, CNRS/Université de la Méditerranée, OSU/Centre d'Océanologie de Marseille, Campus de Luminy, Marseille Cedex, France.

${ }^{3}$ Department of Biological Sciences, University of Southern California, Los Angeles, California, USA.

Copyright 2008 by the American Geophysical Union. 0886-6236/08/2007GB003124
}

Panzeca et al., 2006; Bertrand et al., 2007; Gobler et al., 2007].

[3] The biogeochemical cycling of $\mathrm{Co}$ has been wellstudied especially in regards to its function in the enzyme carbonic anhydrase, where it has been shown to substitute for $\mathrm{Zn}$ in some phytoplankton species [Price and Morel, 1990; Sunda and Huntsman, 1995; Yee and Morel, 1996]. In addition, de novo synthesis of vitamin $\mathrm{B}_{12}$ also requires $\mathrm{Co}$ [Raux et al., 2000; Martens et al., 2002], whose total dissolved concentrations in the open ocean are in the picomolar range (5-105 pmol L ${ }^{-1}$ [Knauer et al., 1982; Saito and Moffett, 2002]). Moreover, only a small fraction (fM) of the total dissolved Co pool is in the free ionic, or bioavailable form [Ellwood and van den Berg, 2001]. Therefore, vitamin $\mathrm{B}_{12}$ synthesis could potentially be limited by Co availability. However, no field study has evaluated whether Co abundance influences the production and distribution of this important organic cofactor in oceanic surface waters.

[4] In order to test our hypothesis that ambient vitamin $\mathrm{B}_{12}$ distributions are influenced by Co availability, we measured dissolved $\mathrm{B}_{12}$ concurrently with Co concentrations in the water column and in phytoplankton in surface waters of the North Atlantic Ocean. In addition, shipboard Co amendment experiments were conducted using phytoplankton communities collected in two contrasting oceanographic regimes to evaluate whether the production of vitamin $\mathrm{B}_{12}$ is limited by this trace element. One experiment took place on the Iceland Shelf, a neritic environment where dissolved Co levels were expected to be relatively high, and the other in the open waters of the North Atlantic, where 


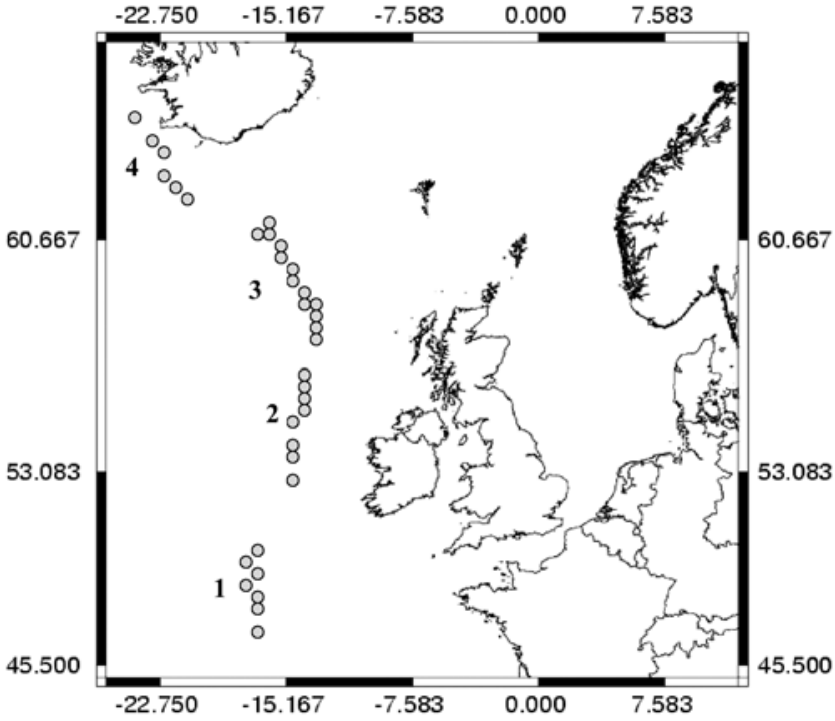

Figure 1. Map of sampling transect in the North Atlantic (start $47.10^{\circ} \mathrm{N}, 20.07^{\circ} \mathrm{W}$; end $66.34^{\circ} \mathrm{N}, 24.58^{\circ} \mathrm{W}$ ). Circles represent sampling locations (region $1, \mathrm{n}=8$; region $2, \mathrm{n}=$ 8 ; region $3, \mathrm{n}=15$; region $4, \mathrm{n}=10$ ). Numbers represent sampling regions $1-4$.

dissolved Co levels were presumed to be very low. Furthermore, in order to validate the importance of $\mathrm{Co}$ for $\mathrm{B}_{12}$ synthesis we also measured ambient concentrations and production of vitamin $\mathrm{B}_{1}$, which does not require $\mathrm{Co}$ for its biosynthesis.

\section{Materials and Methods}

\subsection{Sample Collection and Analysis}

[5] Samples were collected on the R/V Seward Johnson as part of the North Atlantic Spring Bloom (NASB) 2005 project from 6 June 2005 to 11 July 2005 along four geographical transects from the Azores to Iceland (Figure 1). The North Atlantic bloom is one of the most dramatic and predictable biological events in the world ocean [Esaias et al., 1986]. The obvious implications of this regional phytoplankton bloom for ocean carbon and nutrient cycling led to its selection as the first study site for the Joint Global Ocean Flux Study (JGOFS), during the North Atlantic Bloom Experiment (NABE) in 1989-1990 [Ducklow and Harris, 1993; Harrison et al., 1993]. Integrated primary production during the bloom can reach levels of 50-150 mmol C m $\mathrm{d}^{-1}$ [Lochte et al., 1993; Chipman et al., 1993]. Investigators on the NASB cruise determined how biological community structure correlates with regional biogeochemistry (Leblanc et al., manuscript in preparation, 2008), as well as possible future climate change-driven influences on the bloom [Feng et al. [2008]; J. M. Rose et al., The effects of increased $\mathrm{pCO}_{2}$ and temperature on the North Atlantic Spring Bloom: II, Microzooplankton dynamics, submitted to Limnology and Oceanography, 2008].
[6] The study area was divided into four provinces based on water temperature, salinity and known oceanic circulation patterns. Subtropical waters influenced region 1 (average temperature and salinity \pm standard deviations: $14.5^{\circ} \mathrm{C} \pm$ $0.73,35.4 \pm 0.10 \%$ ) while region 2 , located over the Rockhall Hatton Plateau, was influenced by waters of the North Atlantic Current $\left(12.0 \pm 0.81^{\circ} \mathrm{C}, 35.3 \pm 0.03 \%\right.$ \%). Region 3 was located in the deep Iceland Basin (11 \pm $0.43^{\circ} \mathrm{C}, 35.2 \pm 0.03 \%$ ) and region $4\left(9.9 \pm 0.79^{\circ} \mathrm{C}, 35.0 \pm\right.$ $0.22 \%$ ) comprises the shallow areas of the Iceland Shelf (Figure 1). Phytoplankton communities varied in each region, with region 1 phytoplankton typical of a central gyre community (cyanobacteria and nanoflagellates). A mixture of coccolithophores, diatoms and dinoflagellates dominated waters in region 2, while coccolithophores dominated phytoplankton community composition in the north (regions 3 and 4, Leblanc et al., manuscript in preparation, 2008).

[7] Surface water samples were collected and analyzed for inorganic nutrients $\left(\mathrm{PO}_{4}^{3-}, \mathrm{NO}_{3}^{-}\right)$, total chlorophyll $a$, bacterial productivity, dissolved vitamins $\left(\mathrm{B}_{12}\right.$, and $\left.\mathrm{B}_{1}\right)$ and $\mathrm{Co}$ in different pools (total dissolved, labile dissolved and intracellular phytoplankton). Bacterial productivity, inorganic nutrients $\left(\mathrm{PO}_{4}^{3-}, \mathrm{NO}_{3}^{-}\right)$and total chlorophyll $a$ samples were collected from a Niskin Bottle Rosette Sampler. Inorganic nutrients $\left(\mathrm{PO}_{4}^{3-}, \mathrm{NO}_{3}^{-}\right)$and total chlorophyll $a$ were quantified by standard protocols [Parsons et al., 1984] while bacterial productivity was measured by ${ }^{3} \mathrm{H}$ leucine incorporation after Kirchman [1993]. Additional surface water samples (total, labile, intracellular $\mathrm{Co} ; \mathrm{B}_{1}, 12$ ) were pumped directly on-board using a weighted tow-fish and acid-washed Teflon ${ }^{\circledR}$ tubing. Samples for total and labile dissolved Co analyses were filtered through $0.22 \mu \mathrm{m}$ polypropylene capsule filters and collected in 1-L acidwashed LDPE bottles. Samples for intracellular Co were collected on $0.4 \mu \mathrm{m}$ acid-washed polycarbonate filters and quantified using the oxalate wash method described by Tovar-Sanchez et al. [2003]. These values were normalized to $\mathrm{P}$ as the above method also quantifies intracellular $\mathrm{P}$ [Sañudo-Wilhelmy et al., 2004]. Dissolved vitamin ( $\mathrm{B}_{1}$ and $\mathrm{B}_{12}$ ) samples were collected in the same way as the dissolved Co, but in 4-L collapsible cubitainers. Filtered samples for total dissolved and labile Co measurements were preconcentrated using established protocols [Bruland et al., 1979; Beck and Sañudo-Wilhelmy, 2007] and quantified by High Resolution Inductively Coupled Plasma Mass Spectrometry (Thermo Finnegan Element 2). The portion of the total dissolved pool that was extracted onto preconditioned Chelex-100 resin at a flow rate of $10 \mathrm{ml} / \mathrm{min}$ was operationally defined as the kinetically labile Co species [Beck and Sañudo-Wilhelmy, 2007]. For vitamin analyses, $4 \mathrm{~L}$ of seawater were solid-phase extracted on board and analyzed by Reversed Phase High Performance Liquid Chromatography according to the method of Okbamichael and Sañudo-Wilhelmy [2004, 2005]. Methodological relative standard deviation values for replicated analyses were below $10 \%$ for inorganic nutrients and dissolved Bvitamins, while recoveries of dissolved Co were well-within $10 \%$ of certified reference materials. 


\subsection{Co Addition Experiments}

[8] Two Co amendment experiments were conducted to quantify $\mathrm{B}_{12}$ and $\mathrm{B}_{1}$ production; one in region 2 typical of open ocean conditions, and another in region 4 using water from the Iceland Shelf. Inorganic nutrient concentrations at the onset of amendment experiments in region 2 were $4.3 \mu \mathrm{mol} \mathrm{L}{ }^{-1} \mathrm{NO}_{3}^{-}$and $0.25 \mu \mathrm{mol} \mathrm{L}{ }^{-1} \mathrm{PO}_{4}^{3-}$, whereas in region 4 inorganic nutrient concentrations were $6.8 \mu \mathrm{mol} \mathrm{L} \mathrm{L}^{-1} \quad \mathrm{NO}_{3}^{-}$and $0.45 \mu \mathrm{mol} \mathrm{L^{-1 }} \mathrm{PO}_{4}^{3-}$. Similarly, ambient total dissolved and labile dissolved $\mathrm{Co}$

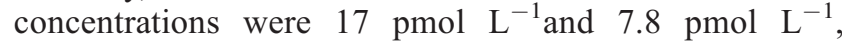
respectively, in region 2 and about two times higher in region 4 (32 pmol $\mathrm{L}^{-1}$ total dissolved, $12.7 \mathrm{pmol} \mathrm{L}^{-1}$ labile dissolved). Ambient dissolved $\mathrm{B}_{12}$ concentrations were 0.67 and $1.9 \mathrm{pmol} \mathrm{L}^{-1}$, and $\mathrm{B}_{1}$ levels were 2.6 and 3.7 pmol $\mathrm{L}^{-1}$ in regions 2 and 4 , respectively.

[9] Phytoplankton community composition determined microscopically at both stations was dominated by Emiliana huxleyi and other coccolithophores (Leblanc et al., manuscript in preparation, 2008). Unfiltered seawater for the amendment experiments was collected in 4-L clear polycarbonate bottles in the same manner as surface water Co samples. The experiment consisted of 6 bottles; 2 initials, 2 controls, and $2 \mathrm{Co}$ amended $\left(2.0 \mathrm{nmol} \mathrm{L}{ }^{-1}\right.$ in region 2 and $0.2 \mathrm{nmol} \mathrm{L}^{-1}$ in region 4). In addition, 2 bottles were also amended with $B_{12}$ at the same locations $\left(100 \mathrm{pmol} \mathrm{L}^{-1}\right.$ in both regions) to determine the potential effect of $\mathrm{B}_{12}$ on algal biomass. All experimental samples were handled in a class-100 trace metal clean van, and were then placed in a deckboard incubator at ambient temperature and $~ 30 \%$ of surface light intensity for $3 \mathrm{~d}$. Subsamples were collected for dissolved $\mathrm{B}_{12}, \mathrm{~B}_{1}$ and algal biomass on day 1 and again at the end of the experiment ( $3 \mathrm{~d}$ later) and analyzed as described above.

\subsection{Statistical Analysis}

[10] To validate differences in measured total, labile dissolved $\mathrm{Co}$, and dissolved $\mathrm{B}_{12}$ between study regions a One-Way Analysis of Variance (ANOVA) was performed on the mean of total measurements within each region.

\section{Results and Discussion}

\subsection{Spatial Trends in Dissolved Constituents}

[11] Total dissolved surface concentrations of vitamin $\mathrm{B}_{12}$ ranged from $0.1-2.5 \mathrm{pmol} \mathrm{L}^{1}$ along the sampling transects (Figure 2a). Generally, mean concentrations increased from south to north (mean: region $1,0.7 \mathrm{pmol} \mathrm{L}^{-1}$; region $2,0.5 \mathrm{pmol} \mathrm{L}^{-1}$; region $3,0.7 \mathrm{pmol} \mathrm{L}^{-1}$; region 4 , 1.4 pmol $\left.\mathrm{L}^{-1}\right)$. Mean total dissolved $\mathrm{B}_{12}$ concentrations were not significantly different in regions $1-3$ (one-way ANOVA, $p=0.3$ ), while mean $\mathrm{B}_{12}$ concentrations nearly doubled from region 1 to region 4 (one-way ANOVA; $p=$ $0.001)$. The range of $B_{12}$ measured in this study was comparable to concentrations measured in the Southern Ocean (0.3-2.4 pmol L ${ }^{-1}$ [Panzeca, 2007]), and up to two orders of magnitude lower than those measured in temperate coastal embayments $\left(5-87\right.$ pmol L ${ }^{-1}$ [SañudoWilhelmy et al., 2006; Gobler et al., 2007]).
[12] Vitamin $\mathrm{B}_{12}$ distributions were similar to spatial patterns of bacterial productivity, as both parameters show a general increase from region 1 to region 4 (Figures $2 \mathrm{a}$ and 2b). Bacterial productivity ranged from $20-103$ pmol ${ }^{3} \mathrm{H}$ leucine $\mathrm{L}^{-1} \mathrm{hr}^{-1}$, and was relatively uniform in regions 1 and 2 with mean values of 31 and $33 \mathrm{pmol}^{3} \mathrm{H}$ leucine $\mathrm{L}^{-1}$ $\mathrm{hr}^{-1}$, respectively (Figure $2 \mathrm{~b}$ ). Similar to total dissolved $\mathrm{B}_{12}$ distributions, bacterial productivity doubled from region 1 (31 pmol ${ }^{3} \mathrm{H}$ leucine $\left.\mathrm{L}^{-1} \mathrm{hr}^{-1}\right)$ to region $4\left(67 \mathrm{pmol}^{3} \mathrm{H}\right.$ leucine $\mathrm{L}^{-1} \mathrm{hr}^{-1}$ ). These analogous distributions are not unexpected since bacteria are the primary producers of this organic growth factor [Raux et al., 2000; Martens et al., 2002].

[13] The same spatial trend was also observed for algal biomass (as total chlorophyll $a$ ). Mean chlorophyll $a$ concentrations were $0.75,1.3,2.6$, and $3.2 \mu \mathrm{g} \mathrm{L}^{-1}$ in regions $1-$ 4 , respectively (Figure $2 \mathrm{c}$ ). These results are contrary to what has been observed in coastal systems where algal biomass showed an inverse correlation with dissolved vitamin $\mathrm{B}_{12}$ [Sañudo-Wilhelmy et al., 2006]. Concentrations of inorganic nutrients $\mathrm{PO}_{4}^{3-}$ and $\mathrm{NO}_{3}^{-}$increased from regions $1-3$ (mean $\mathrm{PO}_{4}^{3-}, \mathrm{NO}_{3}^{-}\left(\mu \mathrm{mol} \mathrm{L}{ }^{-1}\right)$ : region $1,0.14,2.5$; region $2,0.18$, 3.3; region $3,0.3,4.3)$ similar to the above parameters, but decreased in region 4 (mean $\mathrm{PO}_{4}^{3-}, \mathrm{NO}_{3}^{-}\left(\mu \mathrm{mol} \mathrm{L}{ }^{-1}\right)$ : 0.24 , 2.8). It is unclear whether those distributions reflect differences in inorganic nutrient inputs within the different sampling regions due to vertical advection and terrestrial runoff, or increased algal uptake in region 4 .

[14] Similar to the spatial distributions of total dissolved $\mathrm{B}_{12}$, concentrations of total dissolved Co were also not significantly different within regions 1-3 (one-way ANOVA; $\mathrm{P}=0.6$ ), but were significantly higher (one-way ANOVA; $p=0.002$ ) in region 4 (mean: region 1,19 pmol $\mathrm{L}^{-1}$; region 2, 25 pmol L ${ }^{-1}$; region $3,26 \mathrm{pmol} \mathrm{L}^{-1}$; region 4, $45 \mathrm{pmol} \mathrm{L}^{-1}$; Figure 2d). These concentrations are in agreement with those reported previously for Atlantic (5$87 \mathrm{pmol} \mathrm{L}^{-1}$ [Saito and Moffett, 2002]) and Pacific waters (30-105 pmol L ${ }^{-1}$ [Knauer et al., 1982]). Spatial trends in labile dissolved Co concentrations were also similar to the gradients observed for the total dissolved $\mathrm{Co}$ and $\mathrm{B}_{12}$ pools (Figure 2e), and increased from region 1 to region 4 (mean concentrations of 4 pmol L ${ }^{-1}, 5$ pmol L ${ }^{-1}, 5 \mathrm{pmol} \mathrm{L}^{-1}$, and 16 pmol $\mathrm{L}^{-1}$ from region 1 to 4 respectively; Figure 2e). This kinetically labile, and potentially more bioavailable Co fraction [Campbell, 1995] accounted for about 20-40\% of the total dissolved Co pool.

[15] B-vitamins are chemically labile organic molecules with half-lives in seawater of $<24 \mathrm{~h}$ [Gold et al., 1966; Carlucci et al., 1969], suggesting that elevated concentrations must generally be associated with local production. Thus, similar spatial trends in $\mathrm{B}_{12}$, total dissolved, and labile dissolved Co pools (Figure 2) suggest that $\mathrm{B}_{12}$ synthesis could be responsive to the availability of this trace element. Increasing Co concentrations from south (region 1) to north (region 4) may be partially driven by inputs from coastal margins (from reduced sediments and/or freshwater sources [Knauer et al., 1982; Sañudo-Wilhelmy and Flegal, 1996]). Consistent with a coastal source, the highest levels of Co (and $\mathrm{B}_{12}$ ) were measured in the low-salinity $(35.0 \pm 0.06 \%$ ) waters of the continental shelf in region 4 . In contrast, the 

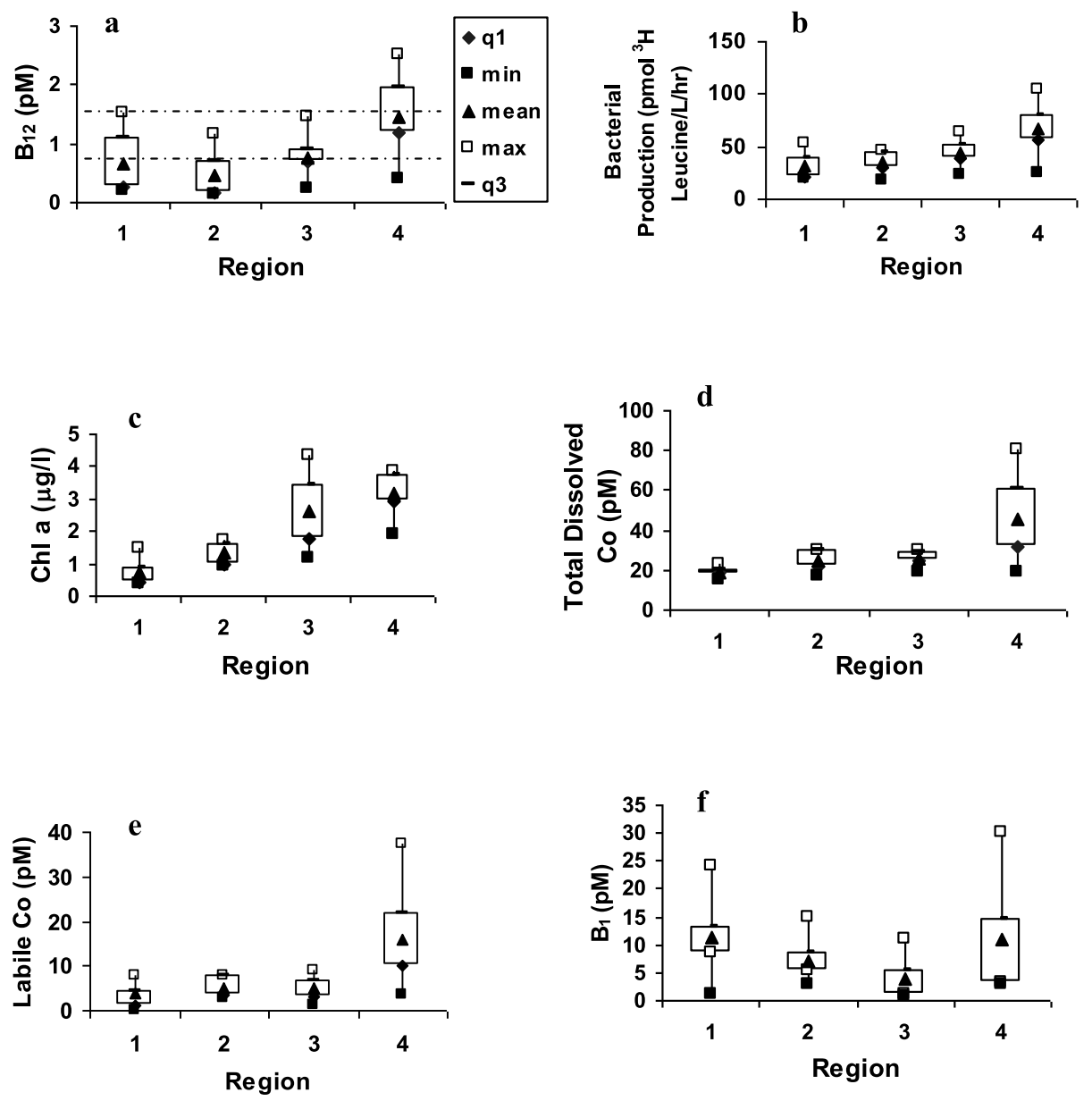

Figure 2. Box and whisker plots of (a) total dissolved $\mathrm{B}_{12}$, horizontal lines represent $\mathrm{K}_{\mathrm{s}}$ values reported by Droop [2007] (see text); (b) bacterial productivity; (c) total Chl; (d) total dissolved Co; (e) labile dissolved Co; and (f) total dissolved $\mathrm{B}_{1}$. Quartile 1 (q1) represents the 25th percentile and Quartile 3 (q3) represents the 75 th percentile.

lowest ambient levels of both $\mathrm{Co}$ and $\mathrm{B}_{12}$ were detected farther south (region $1 ; 35.4 \pm 0.02 \%$ ) in an area dominated by subtropical gyre waters distant from any coastal source.

[16] The south to north gradient of dissolved $B_{1}$ was not as prominent as that observed for $\mathrm{B}_{12}$ and $\mathrm{Co}$. The range of total dissolved $\mathrm{B}_{1}$ concentrations was highest in region 4 (range; $2.8-30$ pmol L ${ }^{-1}$ ), although the mean $\mathrm{B}_{1}$ concentrations were highest in region 1 ( $11 \mathrm{pmol} \mathrm{L}^{-1}$; Figure $\left.2 \mathrm{f}\right)$. The lowest $\mathrm{B}_{1}$ levels were measured in regions 2 and 3 (mean: $6.8,4.0 \mathrm{pmol} \mathrm{L}^{-1}$, respectively). Overall, $\mathrm{B}_{1}$ concentrations were five to ten times higher than ambient $B_{12}$ levels, and the two B-vitamin concentrations were not correlated. This decoupling between ambient $\mathrm{B}_{1}$ and $\mathrm{B}_{12}$ distributions could reflect different production and consumption rates, or different cellular requirements of these two vitamins among phytoplankton and bacterial communities. This is consistent with the survey reported by Croft et al. [2006] which showed that of the phytoplankton species surveyed $10 \%$ had a known $\mathrm{B}_{1}$ requirement versus 50\% which required an exogenous supply of $\mathrm{B}_{12}$.

\subsection{Importance of Cobalt for Phytoplankton Dynamics and $B_{12}$ Synthesis in the North Atlantic}

[17] To evaluate the potential for Co and vitamin $B_{12}$ limitation of phytoplankton growth in the North Atlantic, we compared the water column and intracellular phytoplankton stoichiometric ratios measured during our study with those reported in the literature (Figure 3). Labile dissolved Co: total dissolved $\mathrm{P}$ ratios (range, mmol Co:mol $\mathrm{PO}_{4}^{3-}$ : region $1,0.001-0.2$; region $2,0.01-0.04$; region 3 , $0.01-0.03$; region $4,0.004-0.4$ ) were on average $1-2$ orders of magnitude lower than intracellular Co:P ratios measured during this study in the field-collected phytoplankton (range, 0.12-6.2 mmol Co:mol $\mathrm{PO}_{4}^{3-}$, Figure 3). Lowest mean intracellular Co:P (0.12 mmol Co:mol $\left.\mathrm{PO}_{4}^{3-}\right)$ was found in region 1 and the highest mean ratio $(2 \mathrm{mmol}$ $\mathrm{Co}: \mathrm{mol} \mathrm{PO}_{4}^{3-}$ ) in region 4 (Figure $3 \mathrm{~b}$ ). These stoichiometric 

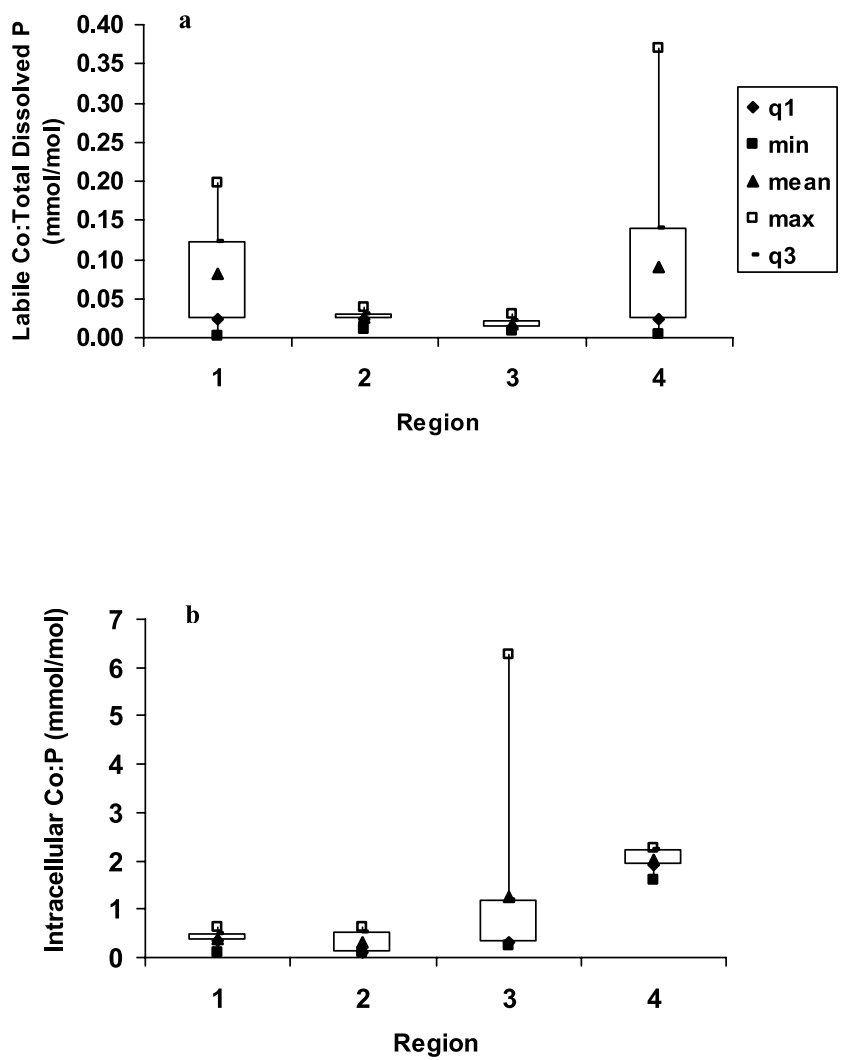

Figure 3. (a) Labile dissolved Co:total dissolved $\mathrm{P}$ (mmol:mol), (b) intracellular Co:P (mmol:mol). All ratios reported are normalized to P. Quartile 1 (q1) represents the 25th percentile and Quartile 3 (q3) represents the 75th percentile.

calculations suggest that phytoplankton were not Co-limited during our study. This assumption is consistent with our field amendment experiments which showed that Co additions did not enhance phytoplankton biomass over unamended control incubations (total chl $a$; one-way ANOVA; P $>0.5$ ). Furthermore, the intracellular Co:P ratios found in the field-collected phytoplankton populations are in agreement with those reported in cultures of diatoms and coccolithophorids (0.06-20 mmol Co:mol $\mathrm{PO}_{4}^{3-}$ [Sunda and Huntsman, 1995; Ho et al., 2003]).

[18] Although Co availability did not seem to limit phytoplankton growth in the North Atlantic during our study, the availability of this trace metal may exert control over $\mathrm{B}_{12}$ synthesis in areas where ambient Co concentrations are low. Consistent with that hypothesis, Co additions increased $\mathrm{B}_{12}$ concentrations by two-fold over unamended controls in region 2 (Figure $4 \mathrm{a}$ ), where levels of dissolved Co (and $\mathrm{B}_{12}$ ) were the lowest $\left(17.1 \mathrm{pmol} \mathrm{L}^{-1} \mathrm{Co} ; 0.67 \mathrm{pmol} \mathrm{L}^{-1} \mathrm{~B}_{12}\right.$; Figure 2). In contrast, there was no statistically significant (one-way ANOVA; $p>0.5$ ) increase in $\mathrm{B}_{12}$ production over control incubations in waters from region 4 over the Iceland Shelf (Figure $4 \mathrm{a}$ ) where ambient $\mathrm{Co}$ and $\mathrm{B}_{12}$ levels were among the highest $\left(32\right.$ pmol L ${ }^{-1} \mathrm{Co} ; 1.9 \mathrm{pmol} \mathrm{L}^{-1} \mathrm{~B}_{12}$; Figure 2). However, since the concentration of Co added in region 4 was ten times lower than the concentration added in region 2 , we cannot totally rule out the fact that ambient $\mathrm{Co}$ concentration did not limit $\mathrm{B}_{12}$ synthesis in region 4 . Furthermore, $B_{1}$ production showed no response to the $\mathrm{Co}$ additions, as no difference (one-way ANOVA; $p>0.5$ ) was observed over control amendments in either location (Figure $4 \mathrm{~b}$ ). These results were not unexpected given that $\mathrm{Co}$ is not required for $\mathrm{B}_{1}$ synthesis. Although Co concentrations added in our amendments were relatively high $(0.2-$ $2 \mathrm{nmol} \mathrm{L}^{-1}$ ), we believe that our Co additions did not induce a deleterious response as previous Co enrichment studies have shown no negative affect on phytoplankton growth at added Co concentrations ranging from 3 to $8 \mathrm{nmol} \mathrm{L}^{-1}$

a.

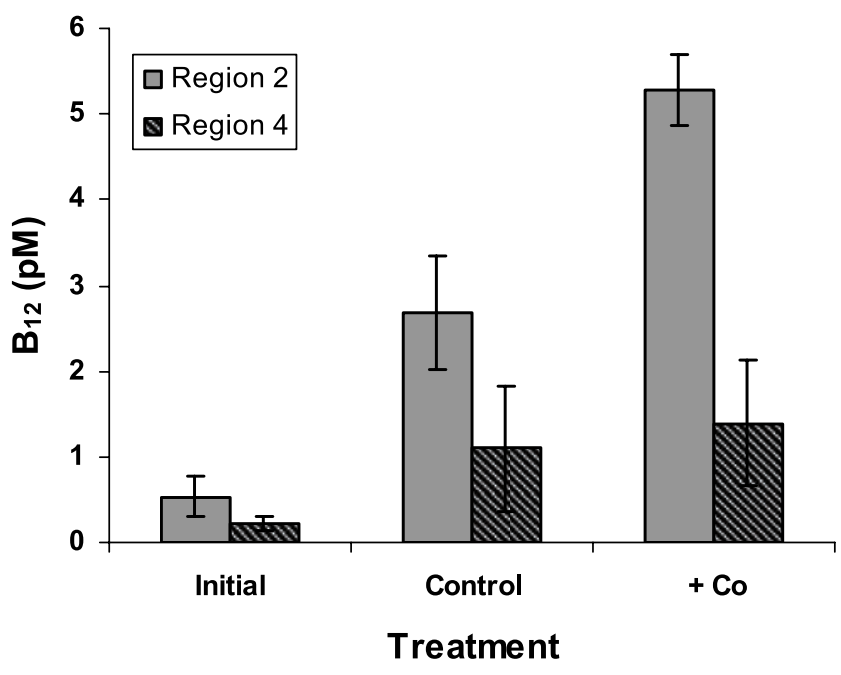

b.

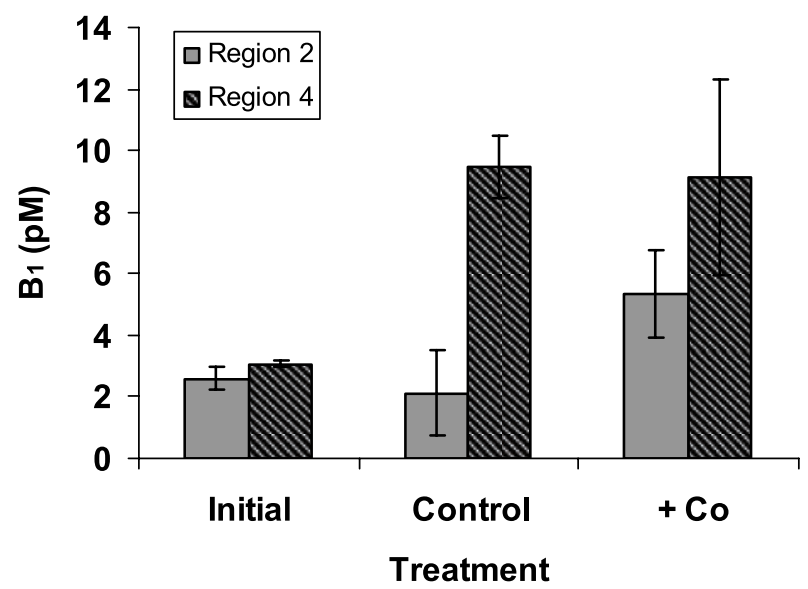

Figure 4. (a) $\mathrm{B}_{12}$ production in $\mathrm{Co}$ additions. $\mathrm{B}_{12}$ concentrations increased over control incubations after $3 \mathrm{~d}$ in experiments conducted in region 2 only. (b) $\mathrm{B}_{1}$ concentration in $\mathrm{Co}$ amendment experiments. Based on the different oceanographic regimes (see methods), it was assumed that ambient Co concentrations were higher in region 4 than in region 2 . Therefore, concentrations of $\mathrm{Co}$ added were $0.2 \mathrm{nmol} \mathrm{L}^{-1}$ and $2.0 \mathrm{nmol} \mathrm{L}{ }^{-1}$, respectively. 
[Granéli and Risinger, 1994; Mitrovic et al., 2004]. Furthermore, inorganic nutrient $\left(\mathrm{NO}_{3}^{-}\right.$and $\left.\mathrm{PO}_{4}^{3-}\right)$ concentrations in the experimental bottles were depleted by $40-60 \%$ at the end of the incubations, suggesting that there was active biological growth during the experiment in region 2 . Future studies will need to establish the minimal Co levels required for $\mathrm{B}_{12}$ synthesis.

[19] It is unclear which species were responsible for the production of vitamin $B_{12}$ in our experiments. However, the production of vitamin $\mathrm{B}_{12}$ could reflect the preferential stimulation of cyanobacteria, which possess the genes for $\mathrm{B}_{12}$ synthesis (www.jgi.doe.gov), and are also known to have a higher Co requirement than eukaryotic phytoplankton [Sunda and Huntsman, 1995; Saito et al., 2002]. An alternative hypothesis is that coccolithophorids were responsible for $\mathrm{B}_{12}$ production as originally proposed by Carlucci and Bowes [1972], as these organisms also have a specific requirement for Co [Sunda and Huntsman, 1995]. Although coccolithophorids were abundant in ambient waters from which our field incubations were conducted, their genomic sequence is not yet available to verify whether or not this organism can indeed produce $\mathrm{B}_{12}$. It is also unclear whether or not vitamin $\mathrm{B}_{12}$ was released by healthy cells during our experiments (Figure 4a). However, excess large corrinoid ring molecules, much like those forming vitamin $\mathrm{B}_{12}$ 's backbone, are known to be secreted to the surrounding environment by prokaryotes when the intracellular levels are high [e.g., Harris et al., 1993].

[20] While Co has a well-accepted function in carbonic anhydrase in phytoplankton [Price and Morel, 1990; Sunda and Huntsman, 1995; Yee and Morel, 1996], our results suggest that this trace metal may also influence the cycling of vitamin $\mathrm{B}_{12}$ in oceanic waters. Given the increased growth response of phytoplankton to $\mathrm{B}_{12}$ additions in an array of marine systems [e.g., Sañudo-Wilhelmy et al., 2006; Panzeca et al., 2006; Bertrand et al., 2007; Gobler et al., $2007]$, it could be argued that limitation of $B_{12}$ synthesis by Co could indirectly influence phytoplankton growth and species composition in some areas of the world ocean.

[21] Acknowledgments. This research was supported by the U.S National Science Foundation (OCE-0351999; OCE-0423418). The authors would like to thank the captain and crew of the RV Seward Johnson for assistance with sample collection. Additional contributions to the manuscript were made by Steven W. Wilhelm for chlorophyll data, Matthew Cottrell and Vanessa Michelou for bacterial productivity measurements, and Mine Berg for inorganic nutrient data.

\section{References}

Beck, A. J., and S. A. Sañudo-Wilhelmy (2007), Impact of water temperature and dissolved oxygen on copper cycling in an urban estuary, Environ. Sci. Technol., 41, 6103-6108.

Bertrand, E. M., M. Saito, J. M. Rose, C. R. Riesselman, M. C. Lohan, A. E. Noble, P. A. Lee, and G. R. DiTullio (2007), Vitamin $B_{12}$ and iron colimitation of phytoplankton growth in the Ross Sea, Limnol. Oceanogr., 52, $1079-1093$.

Bruland, K. W., R. P. Franks, G. A. Knauer, and J. H. Martin (1979), Sampling and analytical methods for the determination of copper, cadmium, zinc, and nickel at the nanogram per liter level in sea-water, Anal. Chim. Acta, 105, 233-245.

Campbell, P. G. C. (1995), Interactions between trace metals and aquatic organisms: A critic of the free ion model, in Metal Speciation and Bioavailability in Aquatic Systems, edited by A. Tessier and D. R. Turner, pp. 45-102, John Wiley \& Sons Ltd., Hoboken, N. J.
Carlucci, A. F., and P. Bowes (1972), Vitamin $\mathrm{B}_{12}$, thiamine and biotin content of marine phytoplankton, J. Phycol., 8, 133-137.

Carlucci, A. F., S. P. Silbernagel, and P. M. Mcnally (1969), Influence of temperature and solar radiation on the persistence of vitamin B12, thiamine, and biotin in seawater, J. Phycol., 5, 302-305.

Chipman, D. W., J. Marra, and T. Takahashi (1993), Primary production at 47-degrees-north-20-degrees-west in the North Atlantic OceanA comparison between the $\mathrm{C}-14$ incubation method and the mixed layer carbon budget, Deep Sea Res., Part II, 40, 151-169.

Croft, M. T., M. J. Warren, and A. G. Smith (2006), Algae need their vitamins, Eukar. Cell., 5, 1175-1183.

Droop, M. R. (2007), Vitamins, phytoplankton, and bacteria: Symbiosis or scavenging?, J. Plankton Res., 29, 107-113.

Ducklow, H. W., and R. P. Harris (1993), Introduction to the JGOFS North Atlantic Bloom experiment, Deep Sea Res., Part II, 40, 1-8.

Ellwood, M. J., and C. M. G. van den Berg (2001), Determination of organic complexation of cobalt in seawater by cathodic stripping voltammetry, Mar. Chem., 72, 33-47.

Esaias, W. E., G. C. Feldman, C. R. McClain, and J. A. Elrod (1986), Monthly satellite-derived phytoplankton pigment distribution for the North Atlantic Ocean basin, Eos Trans. AGU, 67, 835-837.

Feng, Y., M. E. Warner, Y. Zhang, J. Sun, F. X. Fu, J. M. Rose, and D. A. Hutchins (2008), Interactive effects of increased pCO(2), temperature and irradiance on the marine coccolithophone Emiliania huxleyi (Prymnesiophyceae), Eur. J. Phycol., 43, 89-98.

Gobler, C. J., C. Norman, C. Panzeca, G. T. Taylor, and S. A. SañudoWilhelmy (2007), Effects of vitamins $\left(B_{1}, B_{12}\right)$ and inorganic nutrients on algal bloom dynamics in coastal ecosystems, Aquat. Microb. Ecol., 49, $181-194$.

Gold, K., O. A. Roels, and H. Bank (1966), Temperature dependent destruction of thiamine in seawater, Limnol. Oceanogr., 11, 410-413.

Granéli, E., and L. Risinger (1994), Effects of cobalt and vitamin $B_{12}$ on the growth of Chrysochromulina polylepis (Prymnesiophyceae), Mar. Ecol. Prog. Ser., 113, 177-183.

Harris, W. F., R. S. Burkhalter, W. Lin, and R. Timkovich (1993), Enhancement of bacterial porphyrin biosynthesis by exogenous aminolevulinic and isomer specificity, Bioinorg. Chem., 21, 209-220.

Harrison, W. G., E. J. W. Head, E. P. W. Horne, L. I. Irwin, W. K. W. Li, A. R. Longhurst, M. A. Paranjape, and T. Platt (1993), The North Atlantic Bloom Experiment, Deep Sea Res. Part II, 40, 279-305.

Ho, T. Y., A. Quigg, Z. V. Finkel, A. J. Milligan, K. Wyman, P. G. Falkowski, and F. M. M. Morel (2003), The elemental composition of some marine phytoplankton, J. Phycol., 39, 1145-1159.

Kirchman, D. L. (1993), Handbook of Methods in Microbial Ecology, Lewis, Boca Raton, Fla.

Knauer, G. A., J. H. Martin, and R. M. Gordon (1982), Cobalt on Northeast Pacific waters, Nature, 297, 49-51.

Lochte, K., H. W. Ducklow, M. J. R. Fasham, and C. Stienen (1993), Plankton succession and carbon cycling at 47-degrees-north-20-degreeswest during the JGOFS North Atlantic Spring Bloom Experiment, Deep Sea Res., Part II, 40, 91-114.

Martens, J. H., H. Barg, M. J. Warren, and D. Jahn (2002), Microbial production of vitamin $\mathrm{B}_{12}$, Appl. Microbiol. Biotechnol., 58, 275-285.

Mitrovic, S. M., M. Fernañdez-Amandi, L. Mckenzie, A. Furey, and K. J. James (2004), Effects of selenium, iron and cobalt addition to growth and yessotoxin production of the toxic marine dinoflagellate Protoceratium reticulatum in culture, J. Exp. Mar. Biol. Ecol., 313, 337-353.

Okbamichael, M., and S. A. Sañudo-Wilhelmy (2004), A new method for the determination of Vitamin $\mathrm{B}_{12}$ in seawater, Anal. Chim. Acta, 517, 33-38. Okbamichael, M., and S. A. Sanudo-Wilhelmy (2005), Direct determination of vitamin B-1 in seawater by solid-phase extraction and highperformance liquid chromatography quantification, Limnol. Oceanogr. $3,241-246$

Panzeca, C. (2007), B-vitamin cycling in coastal and open ocean systems, Ph.D. dissertation, Stony Brook Univ., Stony Brook, NY.

Panzeca, C., A. Tovar-Sanchez, S. Agustí, I. Reche, C. M. Duarte, G. T. Taylor, and S. A. Sañudo-Wilhelmy (2006), B Vitamins as regulators of phytoplankton dynamics, Eos Trans. AGU, 87, 593-596.

Parsons, T. R., Y. Maita, and C. M. Lalli (1984), A Manual of Chemical and Biological Methods for Seawater Analysis, Elsevier, New York.

Price, N. M., and F. M. M. Morel (1990), Cadmium and cobalt substitution for zinc in a marine diatom, Nature, 344, 658-660.

Raux, E., H. L. Schubert, and M. L. Warren (2000), Biosynthesis of cobalamin (vitamin $\mathrm{B}_{12}$ ): A bacterial conundrum, CMLS, 57, 1880-1893.

Saito, M. A., and J. W. Moffett (2002), Temporal and spatial variability of dissolved Co in the Atlantic Ocean, Geochim Cosmochim. Acta, 66, $1943-1953$ 
Saito, M. A., J. W. Moffett, S. W. Chisholm, and J. B. Waterbury (2002), Cobalt limitation and uptake in Prochlorococcus, Limnol. Oceanogr. 47(6), 1629-1636.

Sañudo-Wilhelmy, S. A., and A. R. Flegal (1996), Trace metal concentrations in the surf zone and in coastal waters off Baja California, Mexico, Environ. Sci. Technol., 30, 1575-1580.

Sañudo-Wilhelmy, S. A., A. Tovar-Sanchez, F. Fu, D. G. Capone, E. J. Carpenter, and D. A. Hutchins (2004), The impact of surface-adsorbed phosphorus on phytoplankton Redfield stoichiometry, Nature, 432, 897 901.

Sañudo-Wilhelmy, S. A., C. Gobler, M. Okbamichael, and G. T. Taylor (2006), Regulation of phytoplankton dynamics by vitamin $\mathrm{B}_{12}$, Geophys. Res. Lett., 33, L04604, doi:10.1029/2005GL025046.

Sunda, W. G., and S. A. Huntsman (1995), Cobalt and zinc interreplacement in marine phytoplankton: Biological and geochemical implications, Limnol. Oceanogr., 40, 1404-1417.

Tovar-Sanchez, A., S. A. Sañudo-Wilhelmy, M. Garcia-Vargas, R. S. Weaver, L. C. Popels, and D. A. Hutchins (2003), A trace metal clean reagent to remove surface-bound iron from marine phytoplankton, Mar. Chem., 85 91-99.

Yee, D., and F. M. M. Morel (1996), In vivo substitution of zinc by cobalt in carbonic anhydrase of a marine diatom, Limnol. Oceanogr., 41, 573577

A. J. Beck, C. Panzeca, and G. T. Taylor, School of Marine and Atmospheric Sciences, Stony Brook University, Stony Brook, NY 117945000, USA.

K. Leblanc, Laboratoire d'Océanographie et de Biogéochimie, UMR 6535 CNRS/Université de la Méditerranée, OSU/Centre d'Océanologie de Marseille, Campus de Luminy, Case 901, 13288, Marseille Cedex 09, France.

D. A. Hutchins and S. A. Sañudo-Wilhelmy, Department of Biological Sciences, University of Southern California, 3616 Trousdale Parkway, Los Angeles, CA 90089-0371, USA. 